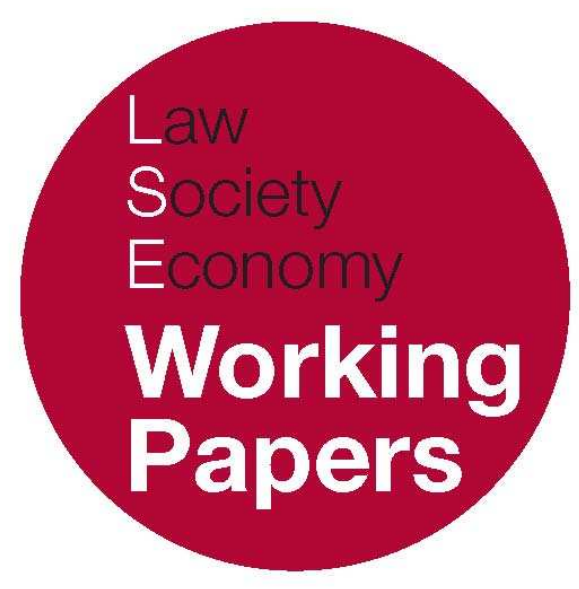

\title{
Regulation Lite: The Rise of Emissions Trading
}

\author{
Robert Baldwin
}

LSE Law, Society and Economy Working Papers 3/2008

London School of Economics and Political Science

Law Department

This paper can be downloaded without charge from LSE Law, Society and Economy Working Papers at: www.lse.ac.uk/collections/law/wps/wps.htm and the Social Sciences Research Network electronic library at: http://ssrn.com/abstract=1091784.

(C) Robert Baldwin. Users may download and/or print one copy to facilitate their private study or for non-commercial research. Users may not engage in further distribution of this material or use it for any profit-making activities or any other form of commercial gain. 


\title{
Regulation Lite: The Rise of Emissions Trading
}

\author{
Robert Baldwin
}

\begin{abstract}
Emissions trading is the governmentally - promoted hope for a sustainable world. In different contexts, trading regimes display varying potential - both in absolute terms and in comparison with other regulatory instruments. Emissions trading, however, is a device that raises urgent issues regarding its objectives, cost-effectiveness, fairness, transparency, and legitimacy. Its use places emphasis on its 'acceptability' and the virtues of regulation that is 'lite' because it is non-threatening to the most powerful interests. Emissions trading is resonant with assumptions that are highly contentious - notably that it is acceptable because it involves no losers, or because, in desperate global circumstances, we have no choice but to use it. There is a need to confront the difficult issues presented by emissions trading; to face the challenges of combining 'market' and 'democratic' systems of legitimation; and to avoid taking refuge in all too comfortable beliefs in cumulative checks and balances.
\end{abstract}

\section{INTRODUCTION}

Emissions trading is the regulatory system that is set to eclipse others as the governmentally-promoted hope for a sustainable world. The Kyoto Protocol ${ }^{1}$ of 1997 established emissions trading as a key instrument in the control of global greenhouse gases and since that date there has followed an explosion of trading regimes and proposals. Most notably, the EU launched its Emissions Trading Scheme in January 2005 and, a year later, the Stern Review advocated the broad

\footnotetext{
${ }^{*}$ London School of Economics and Political Science.

The author thanks Julia Black, Martin Cave, Vanessa Finch, Veerle Heyvaert and Martin Lodge. A final version of this article will be published in the 2008 volume of Regulation and Governance.

${ }^{1}$ Kyoto Protocol to the UN Framework Convention on Climate Change ( FCCC) 1997.
} 
use of use of trading mechanisms to combat climate change. ${ }^{2}$ The Stern approach was quickly endorsed by the UK Government with both Tony Blair ${ }^{3}$ and Gordon Brown ${ }^{4}$ adding demands for the expansion of emissions trading so as to create a 'world wide carbon market.'5

The essence of emissions trading is that governments decide overall bounds to pollution and then issue a number of permits which confer entitlements to emit pollutants and have a total value equal to the settled-upon cumulative limit. ${ }^{6}$ Permit holders are then free to buy and sell their allowances in the marketplace. There is no doubt about the burgeoning popularity and incidence of trading mechanisms but emissions trading may be a device that can too easily be grasped as a politically convenient panacea. Upon further scrutiny it raises an urgent set of issues regarding the objectives that it serves, its efficiency, its fairness and the transparency with which it operates. The rise of emissions trading also introduces new questions concerning our conceptions of good regulation. This article maps out those areas in which emissions trading gives rise to contention and suggests that the current popularity of emissions trading evidences a shift in conceptions of good regulation - away from well- established notions of regulatory merit and towards models that place new emphasis on the notion of 'acceptability' and the virtues of regulation that is 'lite' in so far as it is non-threatening to the most powerful interests. This shift, it will be suggested, may demand that we rethink our approaches to regulatory justification and the processes by which we accord legitimacy to regulatory systems.

\footnotetext{
2 N. Stern, The Economics of Climate Change (H M Treasury, London, 2006) (hereafter 'Stern'); see also the comment: 'Over the past two decades the superiority of market-based instruments has developed into a virtual orthodoxy' in J. Freeman and C. D. Kolstad, Moving to Markets in Environmental Regulation (Oxford: Oxford University Press, 2006) 4.

${ }^{3}$ See Financial Times, 'Emissions Regime Could Feel the Heat', 2 November 2006.

4 The Guardian, 30 October 2006. The Government's energy review of 2006 confirmed that carbon trading would be the 'central element' of the UK's emissions reductions policy framework.

5 The carbon market was worth an estimated 23 billion Euros in 2006, with the largest market being the EU Emissions Trading Scheme (19 billion Euros). Half of all capital driven to the carbon value chain is managed from the UK - see World Bank, The State and Trends of the Carbon Market 2007 (Washington D.C.: World Bank, May 2007)

${ }^{6}$ The literature on emissions trading is very extensive but see generally: T. Tietenberg, Emissions Trading (Washington DC: Resources For the Future, 1985, 2nd ed, 2006); S. Sorrell and J. Skea (eds), Pollution for Sale (Cheltenham: Edward Elgar,1999); OECD, 'Implementing Domestic Tradable Permits for Environmental Protection (Paris: OECD, 1999); id, Greenhouse Gas Emissions Trading and Project-Based Mechanisms (Paris: OECD, 2004); id, Tradable Permits: Policy Evaluation, Design and Reform (Paris: OECD, 2004); D.A. Ellerman, R. Schmalensee, E.M. Bailey, P.L. Joskow and J-P. Montero, Markets for Clean Air (Cambridge: Cambridge University Press, 2000) (hereafter 'Ellerman et al'); R. Kosobud, D. Schreder and M. Briggs, Emissions Trading (New York: Wiley, 2000); J. Norregaard, Controlling Pollution: Using Taxes and Tradeable Permits (Washington: IMF, 2000); D. Ellerman, The Effects on Developing Countries of the Kyoto Protocol and CO2 Emissions Trading (Washington: World Bank, 1998); European Environment Agency, Using the Market for Cost-Effective Environmental Policy (Luxemborg: EEA, 2006); National Audit Office, The UK Emissions Trading Scheme (London: The Stationery Office, 2004); B. Hansjurgens (ed), Emission Trading for Climate Policy (New York: Cambridge University Press, 2005); N. Stern, The Economics of Climate Change (Cambridge: Cambridge University Press, 2007); S. Butzengeiger, R. Betz and S. Bode, Making GHG Emissions Trading Work (Hamburg: HWWA, 2001); A. Michaelowa and S. Butzengeiger (eds), Climate Policy - the EU Emissions Trading Scheme (London: Earthscan, 2005).
} 
Part 1 of the article looks at the development of emissions trading systems, the main varieties of emissions trading arrangement and the claims made for such regimes. Part 2 considers the major challenges and contentious issues presented by emissions trading and Part 3 makes the argument that the rise of emissions trading may involve a sea change in conceptions of regulation and regulatory justification.

\section{PART I: THE DEVELOPMENT OF EMISSIONS TRADING}

It was the 1990s US Acid Rain Programme that established the first large scale, long term environmental programme to rely on the trading of emissions permits. ${ }^{7}$ The UK Emissions Trading Scheme commenced operating in 2002 and, a few years later, the first international emissions trading mechanism was instituted with the EU Emissions Trading Scheme. ${ }^{8}$ This was launched in January 2005 and sought to control greenhouse gas emissions from specific heavy industries in the twenty five EU member states.?

Around the world emissions trading markets have emerged as the method of choice to price carbon. Norway introduced emissions trading in 2005 for major energy plants and heavy industry. New South Wales operates a scheme for electricity retailers and Japan and South Korea are running pilot programmes. ${ }^{10}$ Major plans for new emissions trading markets are to be found in the USA with the Regional Greenhouse Gas Initiative (RGGI) starting its first compliance period from 2009 and California, Switzerland and Canada also plan trading schemes. ${ }^{11}$ Numerous multi-national enterprises have now advocated the use of trading systems in order to control emissions in the most efficient manner and both Shell and BP have been operating internal trading systems since $2002 .{ }^{12}$

\footnotetext{
7 See See OECD, Implementing Domestic Tradable Permits (Paris: OECD, 2002) 13 and, generally, OECD, Lessons from Existing Trading Systems for International Greenhouse Gas Emission Trading (Paris: OECD, 1998) Greenhouse Gas Emissions Trading and Project-Based Mechanism (Paris: OECD, 2004). Environmental Protection Agency (EPA), The United States Experience with Economic Incentives for Protecting the Environment (EPA 2001 : EPA-240-R-01-001). D.A. Ellerman et al.

8 See Directive 2003/87/EC of the European Parliament and of the Council of 13 October 2003 establishing a scheme for greenhouse gas emission allowance trading within the Community and amending Council Directive 96/61/EC. The ETS covers the energy sector; iron and steel production and processing; the mineral, the wool pulp and the paper and card industries. The system provides for: National Allocationa Plans; a system of individual permits; a mechanism to monitor compliance and impose penalties; and a market for emissions trading between the participating parties can trading in European Environment Agency 'Using the Market for Cost-Effective Environment Policy' (Copenhagen: EEA, 2006).

${ }^{9}$ In its first phase from 2005-7 the EU ETS regulated CO2 emissions from installations representing around 40 per cent of EU emissions - see World Bank, n 5 above.

${ }^{10}$ See Stern 329.

${ }^{11}$ See ibid 374. In New Zealand, Individual Transferable Quotes (ITQs) have been used since 1986 for management of commercial fisheries (OECD, 1998, n 7 above).

12 See: http://www.bp.com/sectiongenericarticle.do?categoryId=9007621\&contentId=7014491 (BP's statement that: 'We believe EU ETS should eventually be extended as part of a wider global drive to reduce emissions.').
} 


\section{The Varieties of Emissions Trading MEchanisms}

Emissions trading mechanisms have numerous dimensions and there are many varieties of such systems. A basic distinction lies between 'cap and trade' and 'baseline and credit' approaches. ${ }^{13}$ Under the former, a fixed number of permits are created and each allows the emission of a stipulated amount of pollutant. These permits are allocated or auctioned to firms who are then free to trade them on the open market. ${ }^{14}$ In a baseline and credit regime, companies are given performance targets or 'baselines' - often set with reference to business as usual projections - and they can generate credits by beating their emissions targets. Such credits may then be traded on the open market. With cap and trade there is a fixed supply of permits for trading whereas in baseline and credit the supply of credits for trading depends on the regulatees' performance in generating credits by reducing emissions below baselines. ${ }^{15}$

As for ways to classify trading mechanisms, an authoritative system is that proposed by the US Environmental Protection Agency in 2001.16 This refers to eight basic characteristics ${ }^{17}$ and emissions trading mechanisms vary considerably across such properties. Different characteristics bring different strengths and

\footnotetext{
${ }^{13}$ See OECD 2002, n 7 above.

14 There are four main ways to allocate permits: random access (lotteries); first come first served; administrative rules based on eligibility criteria; and auctions - see T. Tietenberg, 'Tradable Permits in Principle and Practice' in Freeman and Kolstad, n 2 above, 80.

15 In a baseline and credit system aggregate emissions are not fixed in cases where they operate on emission rates (per tonne of output) from individual sources. When targets are based on emission rates, polluters may earn credits by improving emissions rates - even if the total mass of emissions does not drop.

${ }^{16}$ See EPA, The United States Experience With Economic Incentives for Protecting the Environment ( EPA - 240R-01-001). This schema was adopted by the OECD in OECD 2002, n 7 above, 34 .

${ }_{17}$ Scope concerns the nature of restrictions on trading and whether this is limited to a given production unit, a number or type of these, or a geographical area. A further aspect of scope is the industrial level at which controls are aimed. Limits may be targeted upstream (at the level of a given fuel's producers, generators or importers) or downstream (at the level of the consumer). Cap relates to the method of limiting emissions and a key issue is whether the system is cap and trade or baseline and credit. The Commodity Traded refers to the precision with which the traded commodity is defined (Does it involve allowances for future pollution - as in 'offset' trading?). The Distribution of Permits issues are whether permits are auctioned or allocated administratively. (What kind of auction is used? Is allocation based on historical emissions by incumbents - or on the basis of newly decided output levels?). Trading Ratio is a further key characteristic: Do trades operate on a one-to-one basis or do instances trading involve reductions in allowed emissions so that permit values lessen over time? Banking concerns the permissibility of storing permits in excess of current requirements - and the terms for such storage. Monitoring is about methods for recording and monitoring holdings and trades of permits and the steps that are taken to ensure that there is compliance with permit limits. Finally, the Environmental Benefit issue is whether the scheme is designed so that trading produces benefits for the environment (e.g. through 'retirement' of a proportion of allowances on trading).
} 
weaknesses. ${ }^{18}$ Cap and trade systems, for example, are able to fix overall levels of emissions more reliably than baseline and credit approaches. Systems that distribute permits by means of auctions may produce more benefits per unit of emission than processes that 'grandfather' 19 permits to established operators. Regimes that 'retire' percentages of allowances whenever there is trading will produce environmental benefits in a way that non-retirement approaches do not; and different allocations of liability for compliance will affect regulators' capacities to monitor and enforce compliance. Generalisations concerning emissions trading must accordingly be treated with care and it is important to distinguish between the inherent strengths or weaknesses of emissions trading (which are due to the trading process itself) and those contingent matters of performance which flow not from the trading mechanism but from the particular design or characteristics of the scheme ${ }^{20}$ (and its fit with the context of application) ${ }^{21}$ or the intensity of the policy being furthered - for instance the stringency of the pollution abatement target that has been set.22

\section{Why Choose Emissions Trading?}

Advocates of emissions trading mechanisms are growing in number and tend to claim that a number of virtues attach to the device. ${ }^{23} \mathrm{~A}$ first of these is efficiency.

\footnotetext{
${ }^{18}$ For a review of design issues see e.g. OECD, Domestic Transferable Permits for Environmental Management: Design and Implementation (Paris: OECD, 2001); S. Butzengeiger, R. Betz and S. Bode, Making GHG Emissions Trading Work. HWA Discussion Paper 154 (Hamburg: HWWA, 2001).

${ }^{19} \mathrm{Grandfathering}$ is the admission to a scheme - usually on favourable terms - of established operators. It is a common practice within emissions trading systems - see C. Boemare and P.Quirion, 'Implementing Greenhouse Gas Trading in Europe' (2002) 43 Ecological Economics 213,221; N. Keohane, R. Revesz, R. Stavins, 'The Positive Political Economics of Instrument Choice in Environmental Policy' in P. Portney and R. Schwab (eds) Environmental Economics and Public Policy (London: Edward Elgar, 1998).

${ }^{20}$ See T. Tietenberg, 'Tradable Permits in Principle and Practice' in Freeman and Kolstad, n 2 above. On key lessons in the design of emissions trading systems see A.D. Ellerman, 'US Experience with Emissions Trading' and R. Morgenstern, 'Design Issues of a Domestic Emissions Trading Scheme in the USA' both in Hansjurgens, $\mathrm{n} 6$ above. More generally on design see Freeman and Kolstad, n 2 above.

21 That context includes the other regulatory instruments being used in harness with emissions trading and which may control some of the difficulties associated with the device. A further problem in generalising about emissions trading is that most observable regimes comprise mixes of 'command' and 'incentive' approaches - see W. Harrington, R..D. Morgenstern and T. Sterner, Choosing Environmental Policy (Washington DC: Resources for the Future, 2004) (hereafter 'Harrington et al') 240-249.

22 See C. Kolstad, 'Climate Change Policy Viewed from the USA and the Role of Intensity Targets' in Hansjurgens, n 6 above; D. Driesen, 'Design, Trading and Innovation' in Freeman and Kolstad, n 2 above, 437.

23 See generally: B. Ackerman and R. Stewart, 'Reforming Environmental Law' (1985) 37 Stanford Law Review 1333; id, 'Reforming Environmental Law: the Democratic Case for Market incentives' '(1987) 13 Col. J. Environmental Law 171; R. Stavins, 'Policy Instruments for Climate Change' (1997) U Chicago Legal F. 293; N. Keohane, R. Revesz and R. Stavins, 'The Choice of Regulatory Instruments in Environmental Policy (1998) 22 Harv. Env. L. Rev. 313; L. Goulder et al, 'The Cost Effectiveness of Alternative Instruments for Environmental Protection in a Second-Best Setting' (1999) 72 J Pub. Econ.
} 
When the trading of permits to pollute is provided for, this means that the burden of reaching a given level of pollution is minimised. Low cost abaters will be incentivised to reduce pollution levels and sell permits to higher cost abaters with the effect that the set level of emissions is achieved by lowest cost methods. Unlike flat rate command regimes, market mechanisms tailor abatements to the levels that are efficient in each firm or process plant. Overall then, compliance with a given limit is liable to cost less than in a command and control regime. ${ }^{24}$ If inter- country trading is allowed, this ensures that emissions are controlled in the most cost-effective location. ${ }^{25}$ Trading also produces rational controls by generating an international price regarding, for example, carbon emissions. ${ }^{26}$ Regulatory costs are also said too be low because it is claimed that, once established, the trading system runs on its own accord.

A second claimed strength of trading is flexibility. Trading gives managers and enterprises the freedom to choose how to deal with their polluting activities. Managers are less restricted than in command regimes because they are at liberty to decide not only how to reduce emissions in order to reduce permit costs but also the extent of reductions that is efficient for their operations. They are not restricted by an across the board emissions standard or a set of commands that stipulates a particular operational design.

Trading is also said to reduce the dangers of capture by limiting regulatory discretions and by avoiding close relations between regulators and firms. ${ }^{27}$ It is said to do so because, within trading regimes, markets rather than bureaucrats exert restraints on behaviour.

A further posited strength of trading is predictability of outcome. A system established on cap and trade lines is said to offer far more predictable outcomes than, say, a taxation regime. Overall levels of emissions are fixed in a cap and trade regime but, in a taxation system, they are contingent on individual firms' cumulative responses to incentives. This predictability is of value in restraining pollution levels below important threshold points (e.g. levels at which wildlife will

329; N. Keohane, 'Cost Savings from Allowance Trading in the 1990 Clean Air Act' in Freeman and Kolstad, n 2 above; Stern, especially Chapter 15.

${ }^{24}$ See Ellerman et al; T.Tietenberg, Environmental and Natural resource Economics (New York: Harper Collins, 3rd ed, 1996); 'Tradable Permits in Principle and Practice' in Freeman and Kolstad, n 2 above, 74-6; R.N. Stavins, 'Experience With Market-Based Environmental Policy Instruments' in K-G Maler and J Vincent, Handbook of Environmental Economics (Amsterdam: N.Holland/Elsevier Science, 2002); D Burtraw, 'Cost savings Sans Allowances' (Washington DC: Resources for the Future, 1996). Predicted cost savings have ranged from slight (5-10 per cent) to dramatic (95 per cent) - see A. D. Ellerman, 'US Experience with Emissions Trading' in Hansjurgens, n 6 above, 79. For a comparison of trading and command systems that looks at case studies see: W. Harrington and R. Morgenstern, 'International Experience with Competing Approaches to Environmental Policy: Six Paired Cases' in Freeman and Kolstad, n 2 above.

25 Stern 321.

26 ibid 327.

${ }^{27}$ See S. Breyer, Regulation and Its Reform (Cambridge, Mass.: Harvard University Press, 1982). 
be killed) and in calculating such matters as compliance with Kyoto protocol undertakings. ${ }^{28}$

An emissions trading regime is also said to have the potential to deal with distributional issues since it can control the assignment of emissions through the choice of initial allocation method for permits. ${ }^{29}$

An emissions trading system, it is further claimed, stimulates innovation in the techniques and technologies of emissions control. ${ }^{30}$ It does so since a firm that finds a cheaper way to abate can then generate allowances to sell on the market. Such firms, accordingly, will look to the producers of new techniques and technologies to provide them with novel ways to abate. Those producers will, in turn, be incentivised to invest in the appropriate research and development regarding abatement strategies.

Competition and co-ordination issues are said to be handled well by emissions trading mechanisms. On the international stage, for instance, emissions trading schemes can produce a common price (e.g. for carbon) across countries and can do so more easily than processes involving the harmonising of taxes. Trading schemes can thus, it is said, introduce carbon pricing without competitiveness implications between participating countries. ${ }^{31} \mathrm{It}$ is thus a 'very powerful tool in the framework for addressing climate change at an international level.' 32

Finally, emissions trading is claimed to produce political advantages. Trading mechanisms offer a means of introducing controls but also of avoiding major opposition from entrenched incumbents. They can do so by grandfathering allowances and, even when permits are allocated by auction, this allows established actors to defend their positions by exploiting their accumulated wealth. When international regimes are at issue (for example, in the wake of Kyoto) a trading system involves transfers from developed to developing countries (or their enterprises) and this encourages acceptance of the international regime. Advocates of emissions trading also argue that the device enhances the democratic quality of the policymaking process. ${ }^{33}$ It does so, they say, because it focuses discussions clearly on the key issue of the overall level of pollution that should be established - which contrasts with the opacity of command and control systems that centre debates around arcane questions of best available technology versus other formulations of standards. ${ }^{34}$

\footnotetext{
${ }^{28}$ See M. Faure, J. Gupta, A.. Nentjes, Climate Change and the Kyoto Protocol (Cheltenham, UK: Edward Elgar, 2003). 


\section{PART 2: CHALLENGES AND ISSUES}

As indicated at the start, emissions trading mechanisms raise a series of contentious issues. They are not free from difficulties and brief review of emissions trading's main alleged weaknesses and areas of contention will indicate the extent to which emissions trading is a device that needs to be justified. Such a review also provides a useful starting point for considering how the rise of emissions trading evidences a shift in both the way governments and others see the role of regulation and the way that regulation may be legitimised. A preliminary caveat should, however, be entered: as already noted, emissions trading regimes come in widely differing forms and are applied in divergent contexts and this makes generalising a fraught process. In reviewing potential issues of contention it should be emphasised both that some trading systems - for instance the US Acid Rain Programme- have been heralded as considerable successes $^{35}$ and that other policy instruments such as command regimes are by no means problem free ${ }^{36}$.

\section{Do Emissions Trading Systems Target and Secure the Right OBJECTIVES?}

A first issue with emissions trading concerns the objectives to be pursued. A trading process, in itself, offers no benefit to, say, the environment. It does not reduce greenhouse gas emissions. What it does do is to provide a way for a given target to be achieved at lowest cost. In a cap and trade system it is the setting of the cap that provides the opportunity for imposing limits on, say, environmental pollution. Within a baseline and credit regime it is the setting of the baselines. Proponents of emissions trading would, however, argue, that emissions trading systems offer highly implementable ways of reaching whatever targets are decided upon and, that they lend themselves to strategies for tightening controls as trading takes place. ${ }^{37}$ (This can be provided for by requirements that a given percentage of an allowance is 'retired' each time the allowance is traded).

It should be noted, here, that in meeting targets with a trading device, much depends on the mode of defining emissions and distributing allowances. If emissions are defined absolutely (i.e. an absolute limit to discharges is set) this

\footnotetext{
35 See Ellerman et al and especially at 321-2, stating that one should 'extrapolate with care' from the USAcid Rain Program since it was applied in notably favourable circumstances involving accurate emissions monitoring, strong penalties for violations, a small number of relatively large sources of emissions and a focus on specifying emissions limits once and for all.

${ }^{36}$ For comparison of policy instruments see Harrington $e t$ al.

${ }^{37}$ See Stern, Chapter 15 - noting, however, the need for predictability of policy.
} 
targets environmental objectives directly. If, however, emissions are defined relatively (as limits per unit of production) increases in levels of productivity may produce overall increases in emissions even where there is full compliance. ${ }^{38}$

Are emissions trading systems amenable to the institution of environment enhancing targets? Experience with the European Union Emission Trading System (EU ETS) points to a set of potential challenges to be faced - and, notably to the difficulties that are experienced when allocating not through auctions but by means of governmentally- established entitlements. Crucial in the EU ETS were the initial allocations or 'allowances' for Phase 1 of the regime in 2005-7. Incumbent enterprises were extremely concerned to generate generous allowances that would minimise any potential costs and the emissions trading directive left it to Member States to establish allocation plans. As a result, intense lobbying ensued across the EU so that:

In most cases, these efforts resulted in lax emissions targets, complex special allocations to powerful interest groups and, in some cases, even in an over allocation compared to actual emissions. ${ }^{39}$

Additionally, implementation timescales were tight in the EU ETS and a complex set of allocation rules had to be worked to. This meant that most member state regulators had little time in which to process and verify large volumes of representations and pleadings from industry. As a result, it can be argued, the trading scheme proved not to be an effective, low-capture, low-cost regime. Powerful interests were able to exploit their informational advantages and to keep the constraining effects of the ETS at bay. ${ }^{40}$ Environmental pressure groups were thus prompted to protest that the EU ETS had done little to further environmental objectives. As Greenpeace wrote of the EU ETS allocation:

\footnotetext{
38 As would also be the case in a command regime that mandates the use of a particular process or best available technology.

${ }^{39}$ See S Butzengeiger and A Michaelowa, 'The EU Emissions Trading Scheme - Issues and Challenges' (2004) Intereconomics May/June 116,118; G. Svendsen, 'Lobbying and CO2 Trade in the EU' in Hansjurgens, n 6 above; Open Europe, The High Price of Hot Air (London: Open Europe, 2006) (who note that , according to June 2006 figures, Member States handed out permits for 1,829 million tonnes of CO2 in 2005 while emissions were only 1,785 million tonnes. In 2006 carbon emissions grew by 1.25 per cent on 2005, rising to their highest point since Labour came to power - see Financial Times, 'Carbon Emissions Rise' 30 March 2007. Over allocation of allowances has occurred in other regimes -see the discussion of the Los Angeles Regional Clean Air Incentives Market ( RECLAIM) in Tietenberg, n 6 above, 12-13; 129-130.

40 For doubts on the success of the EU ETS in reducing emissions, see House of Commons Environmental Audit Committee, The EU Emissions Trading Scheme: Lessons for the Future HC 70 (Second Report of Session 2006-7) (Para. 4: 'It appears to us that Phase I will have very little impact on carbon emissions across the EU. Allocations of allowances to emit carbon were too generous, and the market price of them consequently too low, to drive a transformation in business strategies and technical processes. Overall, the emissions projections appear to have been inaccurate and inflated, and the national caps derived from them too unambitious.').
} 
Governments massively over allocated $\mathrm{CO} 2$ permits as the market crash in the carbon price has shown ...( the price fell by more than $60 \%$ )... it was because the system relies on future emissions projections as a method to set a cap and then gives out permits for free. Industry simply inflates its own emissions projections in order to ensure it maximises the number of free permits that it gets - permits that, once allocated, have a significant market value. ${ }^{41}$

The pressure group dubbed this: 'a licence for polluters to print money' and the German Environment Minister reported that the EU's four largest power producers had profiteered from the ETS at the expense of consumers ${ }^{42}-$ and had stoked their earnings by between six and eight billion Euros. ${ }^{43}$ Writing in the Guardian, David Gow argued: "The ETS was supposed to be 3.4 billion Euros cheaper than alternative methods of meeting its ambitious Kyoto targets; instead it is costing consumers in untold billions in windfall profits and dividends for power producers." 44

When the UK revised its EU ETS National Allocation Plan for the post 2007 period, its proposed cap on emissions for Phase 2 of the ETS was bigher than for Phase 1 - prompting environmental pressure groups to accuse the UK Government of repeating its over-allocation of permits to the detriment of consumers and the environment. ${ }^{4}$

The experience described raises doubts regarding the amenability of some emissions trading systems to the progressive adjustment of targets in order to improve environmental protections. Command systems have been criticised on this front ${ }^{46}$ but it can be argued that emissions trading regimes are similarly beset by difficulties of complexity, uncertainty and delay when approaching the revision

41 See R. Oakley, 'Greenpeace on the Fiasco of the CO2 ETS' www.energyfuture.org.uk/ index.php?option=com_content\&task=view\&id=149\&It. See also Greenpeace, 'Increasing the Ambition of EU Emissions Trading www.Greenpeace.org/international/press/reports/increase-the-ambition-ofeu.

42 Consumers pay in so far as the recipients of free permits are able to sell these to other firms who will pass through the costs to their customers. See Carbon Trust, The European Emissions Trading Scheme: Implications for Industrial Competitiveness (London: Carbon Trust, 2004) Annex, 31.

43 In the UK, the Department of Trade and Industry published a report by consultants IPA which suggested that UK electricity producers had reaped around $£ 800$ million in windfall profits from the ETS -see IPA Consulting, Implications of the EU Emissions Trading Scheme for the UK Power Generation Sector (IPA Consulting, 11 November 2005) http://www.dti.gov.uk/files/file33199.pdf. See also Open Europe, The High Price of Hot Air: Why the EU Emissions Trading Scheme is an Environmental and Economic Failure, (London: Open Europe, July 2006).

44 D. Gow, 'Power Tool' Guardian Unlimited, May 17, 2006.

45 See Greenpeace, 'Why the European Community Should Repeal the UK's National Allocation Plan for Phase 2 of the ETS' (Greenpeace, June 2002). The UK's proposed NAP was approved by the European Commission in November 2006.

46 See Ackerman and Stewart, 'Reforming Environmental Law: the Democratic Case for Market Incentives', n 23 above, 174. 
of standards and limits. ${ }^{47}$ There will also be difficulties of lobbying and pressures from potential litigants and these are likely to prove to be at least as severe as those encountered in traditional command regimes.

The message to be drawn from the EU ETS is that if allowances are distributed at no cost, there are serious incentives to distort emissions projections so as to create windfalls. One answer to this problem is to allocate allowances by means of auctions. If these are competitive, polluting enterprises will calculate their abatement costs as accurately as they can and then (a) take steps to abate where this is cheaper than purchasing permits, and (b) purchase permits to cover production up to the point of non-profitability.48 Many 'grandfathered' firms will, of course, object to having to pay for emissions that previously had been discharged at no cost. Auctioning, however, can be defended on the grounds that, not only does it avoid dangers of manipulation, but that polluters and the consumers of polluting products should have to pay for the harms that they inflict on the environment. Objections to auctioning may, of course, be less forthcoming from suppliers whose market positions allow them to pass on to consumers the costs of purchasing allowances. ${ }^{49}$

\section{Is Emissions Trading Efficient - Does it Produce Lowest Cost ABATEMENT?}

\section{Innovation and Technology Forcing}

Proponents of emissions trading schemes claim, as seen above, that such mechanisms can usefully drive forward the search for more efficient abatement technologies as traders seek to lower costs..$^{50}$ Emissions traders, it is contended, will look to purchase abatement technologies when the costs of abatement per unit are rendered less than the costs of permits. Sceptics, however, argue that such incentives have limitations and that there are: 'solid reasons to suspect that an emissions trading program does a poorer job of stimulating innovation than a comparably designed traditional regulation. ${ }^{51}$ A central argument is that in, for

\footnotetext{
47 See D. M. Driesen, 'Does Emissions Trading Encourage Innovation?’ (2003) 33 Environmental Law Reporter 10094, 10100. For arguments favouring the abandoning the dichotomy between command and control and economic incentive systems, see D. Driesen, 'Is Emissions Trading an Economic Incentive Programme? Replacing the Command and Control/Economic Incentives Dichotomy' (1998) 55 Washington and Lee Law Review 289 - where it is argued that both regimes involve establishing commands, the creation of incentives, the setting of limits and the monitoring and enforcement of controls.

${ }^{48}$ I.e. the point where the permit and other costs of producing an extra widget exceed the revenue earned from sale of that widget.

${ }^{49}$ Centrica, owners of British Gas, have been reported as backing the idea of auctions for allowances in the EU ETS - see n 44 above.

${ }^{50}$ See e.g. Ackerman and Stewart (1985), n 23 above; Stavins n 23 above; Keohane, n 23 above. Ellerman et al 316, conclude that the US Acid Rain Program did stimulate progress in abatement technology.

${ }^{51}$ See D. Driesen, 'Design, Trading and Innovation' in Freeman and Kolstad, n 2 above, 437; n 47 above (2003) and (1998) where Driesen also argues (at 325) that the incentive for a firm continuously to reduce emissions and sell off permits only operates to the point at which an equilibrium level is established by a programme. Fischer also notes that, where numbers of permits are fixed, reductions in abatement costs
} 
example, a cap and trade regime, the cap sets a limit to emissions and the effect of trading is to concentrate emissions-reducing efforts on those facilities that have the lowest abatement costs - which will tend to be the operators with low-tech systems. Emissions trading, it is said compares poorly with traditional regulation regarding high-end innovation. This is because trading reduces the incentives for high - cost facilities to innovate in order to save costs..$^{52}$ As one critic has contended: 'Why bother making expensive long term structural changes if you can meet your pollution rights from operators that can cut their carbon cheaply?"53 In short, high-end buyers of credits will tend not to innovate but low end sellers will seek to release credits - not by engaging in the cutting-edge development of productive innovations, but by implementing low-tech changes. It might be responded that the scenario described is efficient - that it is better to abate via cheap low-tech means rather than through expensive research and development. Such a response, however, fails to take on board the syndrome of falling abatement costs - the propensity of initially expensive innovations to develop in the longer term (notably through economies of scale) into cheap, efficient abatement mechanisms. The effect of emissions trading, at least under certain conditions, may be to postpone or reduce the chances of discovering newly efficient abatement systems. ${ }^{54}$

Short -term efficiency gains may tend to be purchased in emissions trading regimes at the cost of the development, in the longer term, of new technologies that may revolutionise environmental performance. To give an example: within an emissions trading scheme the fossil-fuel burning electricity utility in the developed country may claim credits for activities undertaken abroad as a substitute for reducing greenhouse gases at home. Had the utility been faced with a command requirement, it might have been stimulated to take more radical steps such as considering changing fuels or employing alternative technologies such as innovative fuel cells or solar energy solutions. ${ }^{55}$

Will emissions trading systems encourage the closure of old polluting premises and the building of innovative, high-tech and low polluting establishments? If a company is considering renewing its plant, the opportunity to

cause permit prices to fall and this progressively reduces incentives to innovate - see C. Fischer, 'Technical Innovation and Design Choices for Emissions Trading and Other Climate Policies' in Hansjurgens, n 6 above. Fischer also makes the point that command and control regimes that apply performance standards will (like taxes per unit of pollution) incentivise innovation but commands that call for the use of particular technologies or operational designs will not incentivise innovation beyond satisfaction of the prescribed design.

52 D. Malueg, 'Emissions Credit Trading and the Incentive to Adopt New Pollution Abatement Technology' (1987) 16 J. Environmental Economics and Management 52. For a comparison of incentive and command instruments as drivers of innovation see Harrington et al, 252-254.

${ }^{53}$ L. Lohmann, 'Carry On Polluting' New Scientist 2 December 2006

${ }^{54}$ Driesen, 'Does Emissions Trading Encourage Innovation?', n 47 above, 10097; Commission on Sustainable Development, Report to the Secretary General, UN Doc. E/CN. 17/2001.PC/20 (2000); OECD 2002, $n 7$ above, 20.

${ }^{55}$ Driesen, 'Does Emissions Trading Encourage innovation?', n 47 above, 10098 
sell off its released allowances will create an incentive to innovate. If, however, governments seek to tighten overall caps by withdrawing allocations when installations are closed, this creates perverse incentives to keep old inefficient units operating in order to preserve the value of those allocations. Similarly, if governments attempt to encourage new enterprises by giving free allowances to new entrants this creates perverse incentives to maximise such allowances by building highly polluting systems. As the Carbon Trust has said of the European regime: 'The EU ETS can even act to subsidise the construction of new carbonintensive coal plants that would not have been built without it, because they receive the revenues of higher electricity prices without paying the cost of their carbon. ${ }^{56}$ When grandfathering is used to allocate permits at the inception of a trading regime, this also may reduce incentives to innovate. ${ }^{57}$ This occurs because such innovations will reduce the value of permits and, accordingly, the wealth of permit holders.

\section{Uncertainty}

A further potential difficulty with emissions trading systems is said to be uncertainty..$^{58}$ In the first place, if firms are familiar with command regimes and are not certain about the longevity of an emissions trading scheme they will not be inclined to make the strategic decisions that are allowed for in trading mechanisms. ${ }^{59}$ Experience with the EU ETS shows how, in a baseline and credit system, excessively generous initial allocations of allowances can produce volatilities in the price of emissions. ${ }^{60}$ Parties considering investing in research and development into abatement technologies may be disincentivised by such volatility and the uncertainties of any potential returns on their investment. ${ }^{6}$ As one commentator wrote of trading uncertainties: 'Our results indicate that firms may respond to uncertainty by adopting a "wait and see" approach.' ${ }^{2}$ The Energy Director of Ernst and Young has argued that movements in carbon prices in the EU ETS had discouraged meaningful investment in carbon reducing technologies and had, instead encouraged the short term trading of positions to optimise

\footnotetext{
${ }^{56}$ See Carbon Trust, Allocation and Competitiveness in the EU ETS (London: Carbon Trust, June 2006) 8.

57 See Boemare and Quirion, n 19 above; S. Milliman and R. Prince, 'Firm Incentives to Promote Technological Change in Pollution Control' (1989) $17 \mathrm{~J}$ Env. Economics and Management 247.

${ }^{58}$ See Stern, Chapter 15 on the need for predictability in carbon policy.

${ }^{59}$ See R. Stavins, 'Implications of the US Experience' in Hansjurgens, $n 6$ above, 67-8.

${ }^{60}$ On continuing volatilities in the EU ETS see World Bank, n 5 above, 12-13. The US Acid Rain Program has avoided huge volatilities but allowance prices, nevertheless, fell from $\$ 154$ to $\$ 64$ from 19941996 and leaped to $\$ 200$ in March 1999 - see Ellerman et al Chapter 11.

${ }^{61}$ See $\mathrm{n} 56$ above, 8 .

${ }^{62}$ S. Ben-David et al, 'Attitudes Towards Risk and Compliance in Emission Permit Markets' (2000) 76 Land Economics 590; Stern 370; W. Blyth and R. Sullivan, 'Climate Change Policy Uncertainties and the Electricity Industry’ Energy, Environment and Development Programme Briefing Paper 06/02 (London: Royal Institute of International Affairs, 2006).
} 
returns and limit risks. ${ }^{63}$ In any regime where there is a cap on permits in supply, small changes in demand can lead to large changes in prices. This volatility is particularly damaging in industries such as electricity generation where investment decisions work to long horizons - these decisions are highly dependent on knowing the price for carbon emissions over time. ${ }^{64}$ When cutbacks in emissions caps are set with reference to Business As Usual (BAU) projections, this process involves particularly high levels of uncertainty since the cutbacks are made 'from moving targets. ${ }^{65}$ This is because a rise in BAU projections will automatically drag up the cap and the number of allowances to emit. Command regimes will involve uncertainties regarding the stringencies of the governmentally-imposed requirements of the future but emissions trading systems can create uncertainties in relation to both the limits that governments or regulators set on caps (or baselines) and the emissions prices that are established in the marketplace. 66

\section{The Health of Markets}

Another major issue in emissions trading is the state of the market. If there is no vigour in the trading of permits there cannot be a strong set of incentives that will influence abatement behaviour. The parties within the system have to be both disposed to trade and able to do so if emissions trading is to operate as an effective control mechanism. Some emissions trading systems have been said to involve healthy markets ${ }^{67}$ but, in others, trading activities have been far lower than expected - and have sometimes been zero. ${ }^{68}$

Experience, says the OECD, demonstrates that emissions trading programmes can take a long time to develop because constraints of acceptability and a lack of familiarity with the instruments can mean that firms do not make use of trading opportunities. ${ }^{69}$ A problem with the first phase of the EU ETS was that, by failing to create a genuine market, it did not encourage investments in renewables and other low carbon technologies. ${ }^{70} \mathrm{~A}$ related difficulty is that if initial allocations of permits are defective and there is governmental correction ex post, this may create further uncertainties in the system as the rules change. ${ }^{71}$

63 Tony Ward, Daily Telegraph, 16 May 2006 , quoted in Open Europe, The High Price of Hot Air (London: Open Europe, 2006).

${ }^{64}$ M. Lockwood, A Rough Guide to Carbon Trading (London: IPPR , 2007) 5 - who notes that in the US sulphur dioxide scheme, prices have had a monthly volatility of ten per cent.

65 See House of Commons Environmental Audit Committee, The EU Emissions Trading Scheme: Lessons for the Future HC 70 (Second Report of Session 2006-7) 7.

66 See Driesen(1998), n 47 above and J. Dennis, 'Smoke for Sale' (1993) 40 UCLA Law Review 1101.

67 See Ellerman et al Chapter 7 (on the US Acid Rain Program).

68 See OECD 2002, n 7 above, 20; R. A. Kraemer et al 'Tradable Permits and Water Resources Protection and Management' Chapter 7; B. Swift, 'The Acid Rain Test' (1997) 14 Environmental F. 17,21 (estimating that in the mid-nineties US Acid Rain programme, only around one to three and a half per cent of allowances were involved in trading).

${ }^{69}$ See OECD (2004), n 6 above and Stavins, n 59 above.

$70 \mathrm{n} 44$ above.

71 See n 56 above, 8 . 


\section{Transaction Costs}

Some emissions trading schemes have gained reputations for low administrative $\operatorname{costs}^{72}$ but others are complex and, particularly when targeted 'downstream' (i.e. towards consumers in the supply chain) will tend to raise difficult issues regarding administrative and transaction costs. ${ }^{73}$ Thus, when the OECD considered controlling pollution by using tradeable permits to ration mobility in the transport sector, it concluded that fuel taxes would be a cheaper solution. The foremost problems with trading were the administrative costs of targeting a large number of mobile sources and the high transaction costs involved in making permits transferable. ${ }^{74}$ The OECD stressed that analyses of the transaction costs of trading systems were the key to measuring value added and should be a focus of ex post evaluation studies of controls. To return to the EU ETS, this has been dubbed 'an administrative nightmare' whose complexities impose huge burdens of an estimated $f^{6} 62$ million on firms and public sector bodies. ${ }^{75}$ These are said to be felt especially by small plants who are covered by the scheme but contribute little to emissions. ${ }^{76}$

\section{Information}

An efficient trading system will be one that is based on reliable data and, within which, there are good information flows. ${ }^{77}$ On this front, an issue with such systems, and notably with baseline and credit approaches ${ }^{78}$, can be their vulnerability to data manipulation and, when allowances are issued at no cost, the incentivising of such manipulation. ${ }^{79}$ The EU ETS, again, has exemplified these difficulties - which include not merely the distortion of information but the emission of supra-normal quantities of pollutants so as to earn higher allowances. ${ }^{80} \mathrm{~A}$ familiar criticism of traditional 'command' regulation is that regulated firms are able to exploit the information asymmetry between regulator and regulated. It is arguable, though, that trading mechanisms do not necessarily overcome this difficulty. In some respects the incentive to manipulate may be worse in an emissions trading mechanism. It is, for instance, linked to the

\footnotetext{
72 See Ellerman et al, 257 (on the US Acid Rain Program). On design factors affecting transactions costs see Tietenberg, n 6 above, 70-71.

${ }^{73}$ See R. N. Stavins, 'Transaction Costs and Tradable Permits' (1995) 29 J Env. Econ. And Mgt. 133; T. Sterner and H. Hammar, 'Designing Instruments for Climate Policy' in Hansjurgens, n 6 above.

74 OECD 2002, n 7 above, 148.

75 Open Europe, n 63 above.

76 ibid 4.

77 See Ellerman et al Chapter 7 (on the development of the market in the US Acid Rain Program).

${ }^{78}$ For contrast, in this respect, with 'cap and trade' systems see Ellerman et al, 318.

79 Open Europe, n 63 above.

${ }^{80} \mathrm{On}$ incentives to inflate historic use in order to gain larger allocations see H. Berland, D. Clark and P. Pederson, 'Rent Seeking and the Regulation of a Natural Resource' (2001) 16 Marine Resource Economics 219.
} 
producing of a firm-specific gain - one that can be expected to bring competitive advantages - rather than to an impact on the stringency of a command standard that will be applied across the board to all relevant firms. ${ }^{81}$

\section{Enforcement}

It should be emphasised that emissions trading markets will generally need regulatory encouragement if they are to develop. ${ }^{82}$ The rules of trading must be enforced and monitored since non-observance of allowances will undermine the value of trading. ${ }^{83} \mathrm{As}$ the Stern Review pointed out: 'A transparent and wellenforced system of measuring and reporting emissions is crucial for securing the environmental credibility of a scheme as well as free trade across plants. ${ }^{34}$ Ceilings on emissions will be valueless if caps and credit regimes are not enforced and enterprises will be reluctant to comply with the terms of trading systems if, due to non-enforcement, they feel that they are competitively disadvantaged. On the international front, confidence in trading systems thus demands not merely that compliance systems are strong across participating nations but that there is agreement on standards for monitoring, reporting and verification of emissions.

Emissions trading schemes, accordingly, do not escape the enforcement challenges that are familiar in command regimes. ${ }^{85}$ Under some conditions, trading schemes have proved conducive to high levels of compliance. ${ }^{86}$ Under other conditions, however, it is arguable that emissions trading systems may render enforcement particularly difficult. Within an international greenhouse gas trading regime, for instance, an enterprise within a developed country will look to buy allocations as cheaply as possible. The lowest prices are likely to be those offered by firms in developing countries and the very lowest from those firms in developing countries whose governments are poorest at monitoring and enforcing. ${ }^{87}$ This will be the case because the selling firms will anticipate that,

\footnotetext{
${ }^{81}$ This is not to deny that in other circumstances the trading process can help to flush out information as when the grandfathering of permits incentivises rent-seeking incumbents to declare their emissions (which helps the regulator to inventorise emissions and sources) see J.M. Sanchez and R. Katz, 'A Market-Based Environmental Policy Experiment in Chile' (2002) 45 JLE 267-287 ; see also S. Penderson, 'Experience Gained with CO2 Cap and Trade in Denmark' OECD Workshop on Ex Post Evaluation of Tradable Permits (Paris, January 2003).

82 On the routine mixing of incentive and command instruments see Harrington et al Chapter 12.

${ }^{83}$ See T. Tietenberg, 'Tradable Permits in Principle and Practice' in Freeman and Kolstad, n 2 above, 71.

${ }^{84}$ Stern Review, 336.

${ }^{85}$ See R. Greenspan Bell, 'Choosing Environmental Policy Institutions in the Real World' and J. Kruger, K. Grover and J. Schreifels, 'Building Institutions to Address Air Pollution in Developing Countries: the Cap and Trade Approach' both in OECD', Emissions Trading and Project Based Mechanisms (OECD, 2002).

${ }^{86}$ See Ellerman et al Chapter 5 on the 'exemplary compliance' in the US Acid Rain Program and Harrington et al, 259 on the US leaded gasoline regime.

87 On the particular difficulties of enforcing emissions trading systems in developing countries see E. Richman, 'Emissions Trading and the Development Critique; Exposing the Threat to Developing Countries' (2003) 36 Int. Law and Politics 133.
} 
thanks to poor enforcement, they can sell their allowances but still carry on emitting at the usual levels.

Emissions trading systems, indeed, may incentivise lack of enforcement and corruption since unethical members of governments will often be able to both reap personal gains and, at the same time, offer home enterprises competitive advantages. They will do so by allowing permits to be sold, emissions levels to be misrepresented and by taking rewards for this. Emissions trading can be said to place heavy stress on enforcement but to involve enforcement under extremely difficult conditions. A special concern at the global level may be that emissions trading mechanisms involve huge verification challenges and create the dangerous illusion that production patterns in the North can be maintained without harming the climate. ${ }^{88}$

\section{Is EMISSIONS TRADING FAIR?}

A fundamental problem with market-based systems of distribution is that spending power holds sway. Such systems have an inherent bias in favour of those parties who possess wealth and they tend to remove power from those who lack resources. ${ }^{89}$ The results of trading may be claimed to be efficient but this does not ensure fairness: ...'trades of rights in the marketplace may lead to a concentration of property and market power, denying small businesses and poor people access rights to necessary resources (e.g. water). ${ }^{90}$

A first difficulty with trading systems is that, if they are to overcome the political hurdles of inception, they tend to have to 'grandfather' existing operators into the system. ${ }^{91}$ If, however, permits to pollute are allocated on the basis of historical or current emission levels, polluters will not 'pay' - they will be rewarded for their records of pollution. ${ }^{92}$ They will, moreover, be placed in positions that allow them to maximise their potential rewards by exploiting their informational advantages and their abilities to manipulate data to their advantage.

\footnotetext{
88 See the Durban Declaration on Climate Trading -www.sinkswatch.org.

${ }^{89}$ See Derek Walls's comment on the Stern Review that: 'Sir Nicholas and his team have reached for their micro-economics textbooks in the way that a Mid-west preacher reaches for his bible' - D Walls, Costing the Earth (www.redpepper.org.uk/Dec2006/dec-06-stern.htm).

90 OECD 2002, n 7 above, 20. Direct action group, Rising Tide describes carbon trading as 'privatisation of the climate' - see Weekly SchNews 29 June 2001.

${ }^{91}$ See L. Raymond, Private Rights in Public Resources (Washington DC: Resources for the Future, 2003); OECD 1998, n 7 above, 39, reports that in New Zealand, the political feasibility of introducing Individual Tradable Quotas in fisheries was "greatly enhanced” by initial allocations based on incumbents' catch histories and "support from key industry players" plus compensation for any 'incumbents' losses.

92 See Stern 333; K. Neuhoff et al, 'Allocations, Incentives and Distortions' (2006) 6 Climate Policy 71; P. Baer et al, 'Equity and Greenhouse Gas Responsibility' (2000) 289 Science 2287. A criticism of the EU ETS has been that some member states of the EU have given their firms emissions targets based on past records whereas others have allocated targets on the basis of forecasts - with the effect of unfairness to firms in the former group who have to purchase permits from firms in the latter group - see Open Europe, n 63 above.
} 
Free allocations, moreover, may result in windfall profits and, as Stern commented: 'Not surprisingly, free permits are generally favoured by existing players in industry. ${ }^{93}$ It is noteworthy here that the history of the UK Emissions Trading Scheme reveals it to have been very much the darling of industry. The idea of greenhouse gas emissions trading entered the British policy agenda after heavy promotion by BP and advocacy by Lord Marshall, the then Chairman of British Airways, who suggested that a business-led institution be established in order to design a trading system for greenhouse gas emissions in the UK. ${ }^{94}$

Fairness, Stern added, demands that historical polluters are not simply rewarded: 'Given the ability to bear costs and historical responsibility for the stock of greenhouse gases, equity requires that rich countries pay a greater share of the costs. ${ }^{95}$ It is arguable, moreover, that the same argument holds in considering domestic trading schemes and that richer polluting concerns should pay a greater share of (capital and ongoing) costs than smaller firms, lesser polluters or new industry entrants. ${ }^{96}$ The difficulty with this argument is that such redistributive approaches always tend to be countered by the regressive effects of trading systems. As for comparisons with other regulatory methods, such as command and control, it has been argued that most empirical studies find that, across a range of policy instruments, the costs of control tend to be borne disproportionately by poorer groups - but that this is especially the case with grandfathered emissions permits. ${ }^{97}$

Nor do fairness issues disappear if permits are allocated by auctioning rather than by free allocation. Auctioning systems tend to distribute permits at far lower administrative cost to both firms and governments than free allocation methods.

\footnotetext{
${ }^{93}$ Stern 333. DTI consultants estimated that the first round of allowances in the EU ETS has produced $£ 800$ million in windfalls and Commission consultants have estimated that airlines could make four billion euros in windfalls if aviation is added to the EU ETS - see n 64 above, 6. See also Congressional Budget Office, 'Who Gains and Who Pays Under Carbon-Allowance Trading?' (June 2000).

94 As a result, business interests set up the Emissions Trading Group (ETG) in June 1999 and the UK ETS emerged from very close collaboration between the Government and major UK companies - see F. von Malmborg and P. Strachan, 'Climate Policy, Ecological Modernism and the UK Emissions Trading Scheme' (2005) 15 European Environment 143.

${ }^{95}$ Stern 472 (Who also notes that the correlation between income or wealth and current or past emissions ' is not exact; but it is strong' - at p. 474.). See also Gordon Brown's comment: Gordon Brown, Speech on Environment Change, Guardian Unlimited. See also the chancellor's speech to the Labour party conference - reported Monday September 25, 2006 Guardian Unlimited: 'And I make this promise: tackling climate change must not be the excuse for rich countries to impose a new environmental colonialism: sheltering an unstainable prosperity at the expense of the development of the poor.'

96 An arguable fairer alternative to historically-based allowances is a benchmarking approach in which permits are issued in a manner that rewards users of clean technologies and penalises dirty systems. Such benchmarking can be based on standardised rates of emissions for particular fuels, technologies or plant sizes. The informational and analytic burdens of establishing such benchmarks are, however, considerable given the complex mixes of fuels and processes to be encountered in industry and such regulatory systems would be highly interventionist in nature.

${ }^{97}$ See I Parry, 'Are Emissions Permits Regressive?' (2004) 47 J of Env. Econ. and Mgt. 364-387; I. Parry, H. Sigman, M. Walls and R.C. Williams, 'The Incidence of Pollution Control Policies' (Washington DC: Resources for the Future, 2005).
} 
Auctioning, however, is, again, a mechanism that favours those incumbents who have the existing resources to make successful bids. The principled objection here is that it is unfair that incumbent polluters - who are the parties who have accumulated wealth at the cost of the environment - should be better positioned than non-polluters or new entrants to the field.

Such unfairness can result in competition distortions - as where incumbents buy up allocations in order to create barriers to market entry. ${ }^{98}$ Small and medium enterprises may also complain that they suffer competitively because they are far less able than large companies to deal with the extensive administrative and informational burdens that are involved in negotiating allowances or organising bids for permits. ${ }^{99}$ On the international stage, it has similarly been argued: 'Only big firms can afford to hire carbon accountants, liaise with officials and pay the costs of getting projects registered with the UN. Yet these are often the companies that local people battle hardest against in defence of their livelihoods and health.' 100

Post Kyoto, a key issue is the development effect of trading systems. ${ }^{101}$ Internationally, emissions trading solutions have been said to involve a double injustice. The effects of existing emissions are felt disproportionately by the less developed nations and they restrict development over coming years. Trading has been called 'colonialism with a modern face' in so far as it is a device that perpetuates and deepens inequalities of access to and control of resources...'It creates the illusion that southern countries are benefiting while masking the fact that it is [the developed] countries and companies which are profiting from access to emissions permits and control of new southern markets. ${ }^{102}$ Critics of trading protest that it offers a means for wealthy countries and companies to escape their historical responsibilities for greenhouse gases, to avoid making emissions reductions in their own operations and to 'defraud developing countries of their rights to use of the global atmosphere.' 103

The charge, then, is that if allocations are set on an historical basis, this both allows currently high emitters to impose environmental damage on other countries and it has the effect of locking the less developed nations into lower levels of development. The linked concern is that in the early years of trading the mechanism allows existing industrialised users to meet their targets at lowest cost and, to avoiding making reductions in home emissions. When, however, developing countries become faced with emissions targets themselves, the cheapest forms of emissions abatement will have been exhausted and only more

\footnotetext{
98 On market power and trading schemes, see R Hahn, 'Market Power and Transferable Property rights' (1984) Quarterly J. of Economics 753.

${ }^{99}$ See Butzengeiger and Michaelowa, n 39 above, 118.

100 n 53 above.

101 See $n 87$ above.

102 See Rising Tide, 'The rising Tide Coalition for Climate Justice Political Statement' (http:// risingtide.org.uk/about/political).

103 See Christian Aid , Global Warming Policy Position Paper November 2000.
} 
expensive high tech forms will be left - at which time industrialised countries will be unwilling to invest abroad. In short, industrialised countries will have gained preferential use of lowest cost abatement methods and reaped a competitive advantage while suppressing development. ${ }^{104}$ Supporters of emissions trading might argue that such considerations can be taken into account when allocations are negotiated but this response makes assumptions about the bargaining power and positions of developing countries (or the altruism of developed countries) that may be unrealistic - a matter to be returned to below.

Firms in less developed countries may, directly or indirectly, be paid to desist from productive enterprise. This may or may not prove politically acceptable. Baer and colleagues argue: 'Developing countries cannot reasonably be expected to restrict their future emissions without being assured of a fair allocation scheme that will not impair their ability to develop. ${ }^{105}$ This demands, they say, not historically-based or auction-based distributions but allocations based on equal rights to the atmospheric commons for every individual. Developing countries, they add, are unlikely to accept permanent restrictions on per capita emissions levels lower than those of industrialised nations.

There is, however, a further argument that suggests that, from a development point of view, it is not enough to allocate emissions rights on a per capita equal rights basis. The effect of this would be to allow existing wealthy polluters to purchase, from poor permit holders, sufficient allocations to allow them to continue to trade at profit maximising levels. There would be a one-off transfer of wealth to poorer firms but these less wealthy players would be paying a price for that transfer - in the form of forfeited opportunities to develop their wealth creative capacity by exploiting those allowances. ${ }^{106}$ They would be giving up not merely present entitlements but also future expectations.

Informational asymmetries would be likely to exaggerate this effect. ${ }^{107}$ To take an example, let us suppose that it is decided internationally to cap pollution from air travel and to do so by establishing a trading scheme in which all companies are allocated $\mathrm{x}$ hours of flights per year (size of allocations to reflect numbers of employees). Wealthy Company A, from a developed country, would, say, purchase the emissions allowances of less developed companies B, C, and D. Would the price paid reflect the true wealth generating potential of those allowances? It is unlikely to do so because, not only has Company A a greater capacity to develop that potential (which is what makes the system efficient) but it has superior information about that potential. After all, that greater potential lies within

\footnotetext{
104 See ibid 7; n 87 above; and Dreisner (1998), n 47 above.

105 Baer et al n 92 above; A. Agggarwal and S. Narain, 'Global Warming in an Unequal World: a case of Environmental Colonialism’ (New Delhi: Centre for Science and Environment, 1991).

106 On the 'development critique' see n 87 above, 149-154; O. Mehmet, Westernising the Third World (London: Routledge, 2nd ed, 1999).

107 See J. Gupta, The Climate Change Convention and Developing Countries: From Conflict to Consensus? (1997) 122

3; n 87 above, 155 .
} 
Company A's own operations. ${ }^{108}$ Companies B, C and D, moreover, are likely, to suffer from non-informational factors that will further undermine their abilities to strike satisfactory deals with Company A - notably they are likely, if sited in a developing country, to be competing, as sellers of allocations, with firms who are less well-informed, less rational and more desperate to sell than themselves. The overall effect of allocations trading on Companies B, C and D is that they receive a one-off payment (a sub-optimal one) and, being excluded from air travel, they will have restricted development potential and are likely to be left ever further behind in the marketplace by Company A. The propensity of companies B,C and D to opt for the short term profit at the expense of the longer term gain is, furthermore, consistent with the message from the risk literature that actors tend to discount the future effects of their actions. ${ }^{109}$

Such informational disadvantages can also be said to be compounded by inequalities of bargaining position and capacity. Thus, Mumma has argued that many developing countries lack the financial, technical and human resources necessary to allow them to negotiate equally with developed nations on emissions trading issues or to evaluate emissions trading programmes thoroughly enough to judge where their longer term interests lie. ${ }^{110}$

According to Stern, one of the major advantages of emissions trading systems is that they allow efficiency and equity to be considered separately.111The UN Framework Convention On Climate Change (UNFCCC) approaches this issue and argues that developed countries should show leadership in tackling emissions, transferring technology, supporting capacity building and financing the incremental costs of emissions reductions. It should do so, says UNFCCC, since equity calls for: the support of poorer countries by wealthier ones on grounds of ability to pay; respect for the principle that the polluter should pay when looking at historical responsibility for pollution; and allowing a rise in emissions in poorer countries in reflection of their relative per capita emissions levels and aspirations for growth and poverty reduction. ${ }^{112}$

These may be sentiments worthy of support but we should be clear about the degree to which emissions trading and reallocative policies pull in opposing

\footnotetext{
108 A healthy market would inform $\mathrm{B}<\mathrm{C}$ and $\mathrm{D}$ concerning the value of the allowances but few real world markets would remove A's information advantage.

109 See, for example, J. Graham and J. Weiner (eds), Risk v. Risk (Cambridge, Mass.: Harvard University Press, 1997); M. Cropper and P. Portney, 'Discounting and the Evaluation of Lifesaving Programs' (1990) 3 J. of Risk and Uncertainty 369; W.K. Viscusi, Fatal Tradeoffs (New York: Oxford University Press, 1992). I am grateful to Julia Black for making this point.

110 A. Mumma, 'The Poverty of Africa's Position at the Climate Change Convention Negotiations' (2000/1) 19 UCLA J. Env. L. and Policy 181; see also Gupta, n 107 above and Richman, n 87 above. Mumma notes (at 202-3) that at the Buenos Aires Conference on Climate Change the US contingent numbered 83 persons; that of the EU 45, and the typical African country sent two to four persons. Developed nations positions were based on arrays of prior publications and large numbers of prior events whereas African positions often had to be devised on the spot.

111 Stern 473; A. Rose and B. Stevens, 'A Dynamic Analysis of Fairness in Global Warming Policy' (1988)

$1 \mathrm{~J}$ of Applied Economics 329, 336.

112 Stern 473.
} 
directions ${ }^{113}$. Such a tension may be so severe as to lead efficiency concerns to swamp those of equity - which negates Stern's argument that emissions trading conveniently allows equity and efficiency issues to be considered separately. Thus, on the post-Rio notion that developed countries would - for reasons of fairness show leadership on climate change, Richman has commented: 'Emissions trading may conflict with the developed country leadership principle in several ways. Most obviously, it allows developed countries to avoid making the early and deep cuts that they committed to at Rio. Though they committed to make the first sacrifices in pollution, and thus production, developed nations can claim that they are meeting their reductions obligations through trading ... emissions trading enables developed nations to "double count" trades as both domestic reductions and assistance to developing countries.'114

Emissions trading exaggerates the effects of inequalities in wealth distribution and offers up wealth creating opportunities to the currently wealthy (and often polluting). Reallocative policies, when linked to emissions trading, may look transparent and worthwhile but three points are worth stressing. First, any reallocative virtues will be due to distributional decisions and restrictions that are placed on the trading mechanism - not to the trading mechanism itself - which can be said to deploy the equal trading rationale to legitimise the unfairness that is produced by inequalities of bargaining positions. Second, any protections for the less well-off, less powerful, less-developed and less well-informed will be operating within a system that is intrinsically skewed in favour of wealth holders. Finally, it can be argued that, as far as fairness is concerned, there are grounds for doubting whether emissions trading systems match up to the performance of command or taxation regimes. The latter, after all, offer across the board approaches, are generally more easily enforced from the centre and are not so vulnerable to distortion in favour of the well-resourced.

\section{Is EMISSIONS Trading ACCOUNTABLE AND TRANSPARENT?}

It has been argued, as noted above, that emissions trading combines democratic accountability with a market mechanism and that trading focuses public attention on decisions about aggregate emissions reductions. ${ }^{115}$ In this regard, it is claimed that emissions trading can offer more democratic accountability than the rulemaking processes of traditional command regulation. Sceptics, however, argue that trading systems have a special complexity that does not facilitate access. Such systems, it is complained, overlay market processes on top of the standard-setting procedures usual to command regimes. This duality, it is said, makes citizen participation in emissions trading programmes more difficult than in traditional

\footnotetext{
113 See n 87 above.

114 See ibid 170

115 Ackerman and Stewart, 'Reforming Environmental Law: the Democratic Case for Market Incentives', n 23 above, 171 .
} 
regulation. ${ }^{116}$ Thus, it has been protested that ... 'the political invisibility of trading schemes involving large companies may be their weakness. The hope is that emissions can be cut cheaply by large corporations with the public virtually unaware that this is going on. But this lack of public awareness is the very thing that makes schemes vulnerable to industry lobbying, resulting in schemes that are ineffective and unfair.' ${ }^{117}$

Special criticisms may apply to systems, such as the EU ETS, in which caps are set in relation to Business As Usual projections. As noted above, such approaches mean that the caps imposed on emissions are liable to change as firms change their forecasts of emissions - a process commented on by the House of Commons Environmental Audit Committee in the following terms:

the practice of setting cutbacks from the moving target of BAU projections creates an obvious lack of transparency....This underlines the need to set reductions from an absolute level of emissions, rather than a baseline of BAU projections which may vary significantly according to the differing assumptions that are fed into them. ${ }^{118}$

The same Committee raised a further issue concerning the transparency of trading regimes. In reporting the effects of the EU ETS, the UK Government had described emissions savings as though these were being made within the UK - but within a trading system it was not certain where any emissions reductions were located, and:

Yet another concern here is that it is not just that the Government is prepared to count $\mathrm{CO}_{2}$ reductions that take place in other countries against its domestic target for $\mathrm{CO}_{2}$ reductions in the UK, but that it is prepared to count reductions of other greenhouse gases, the global warming potential of which can be converted by mathematical formula into $\mathrm{CO}_{2}$-equivalent, against its target for reducing emissions of carbon dioxide. Our concern here is not just regarding transparency, but that many of the projects to reduce exotic gases may be more dubious in terms of their transparency and impact on Business As Usual investment decisions and industrial processes. ${ }^{119}$

Accountability to whom is, of course, also a key issue and one of the recurring criticisms of carbon trading post Kyoto is that it makes policymakers responsive to multinational corporations, not local populations. Thus, some campaigners

\footnotetext{
116 See D. Driesen, 'Free Lunch or Cheap Fix?' The Emissions Trading Idea and the Climate Change Convention' (1998) 26 British Columbia Env.Aff. Law Review 1.

$117 \mathrm{n} 64$ above, 7. As the Financial Times Editorial of 26 April 2007 put it: '...most of the political appeal of markets is that they hide the true costs to consumers. That is why carbon markets exist in the first place.'

118 See House of Commons Environmental Audit Committee, The EU Emissions Trading Scheme: Lessons for the Future HC 70 (Second Report of Session 2006-7) at [19] and [68].

119 ibid, at [22] and [71].
} 
have argued: 'The problems with carbon trading are compounded when carbon credits are used to fund destructive projects like large dams and industrial tree plantations .... This never benefits the local populations who become displaced. ${ }^{120}$

The emissions trading device, moreover, involves a lack of accountability by public officials for the distributional decisions of the market in allocations - for instance regarding the location of the steps taken to abate emissions or the competition consequences of allocations. The emissions trading process, as a result, helps such officials to avoid specificity about the policies being furthered through the trading mechanism and the distributions of costs and benefits, winners and losers. ${ }^{121}$ If, moreover, trading is allowed across jurisdictions, there may be additional problems of perverse incentives. Thus, the purchasers of permits may be induced, by emissions trading, to purchase credits from countries who monitor credit generating activity poorly. Countries involved in selling permits, moreover, will have, as noted, a related incentive not to monitor emissions effectively since such laxity will generate incoming purchases of credits. Monitoring in such countries will tend to be particularly weak if the pollution at issue is not inflicted on that country specifically but is spread across nations as a 'common bad' - as with greenhouse gases. ${ }^{122}$ Such weak monitoring systems will undermine accountability and transparency will be poor.

How, then does emissions trading score on general transparency? One way to summarise on this issue is to evaluate emissions trading processes with reference to Stirton and Lodge's four key transparency mechanisms (information, choice representation and voice). ${ }^{123}$ Information allows informed choices by consumers and others but, as noted, emissions trading supplies little information to the consumers of products regarding the emissions abating efforts of suppliers and manufacturers or the locations at which any abatement efforts are being made. Choice allows consumers to choose the nature of products and goods - but, again, the lack of information provided to consumers in emissions trading systems means that purchasers of products are ill-placed to choose between polluting and nonpolluting products. Representation ensures transparency by allowing access into policy processes to user and interest groups. With emissions trading mechanisms, however, such access is conferred predominantly on those suppliers who buy and sell permits - other groupings are kept at a distance by their non-inclusion in the market ${ }^{124}$. Voice allows user participation and redress. Unfortunately, however, the

\footnotetext{
${ }^{120}$ C. Guerro, quoted in Walls, $\mathrm{n} 89$ above.

121 On the complexity of the UK ETS and the resultant lack of transparency, see von Malmborg and Strachan, n 51 above, 153.

122 See N. Mabey et al, 'Argument in the Greenhouse: the International Economics of Controlling Global Warming' (London: Routledge, 1977) 25; Driesen (1998), n 47 above, 15.

123 L. Stirton and M. Lodge, 'Transparency Mechanisms: Building Publicness into Public Services' (2001) 28 J. Law and Society 471-89.

124 A residual issue, as noted, is the extent to which the deficiencies of emissions trading regimes can be remedied - as where a certification or labelling scheme might address problems of transparency or
} 
consumer user of goods has no access to the trading market and the processes used to set caps and baselines tend to be dominated by conversations between supply firms and governments. Overall, then, serious doubts arise concerning the general transparency of emissions trading processes.

\section{PART 3: THE NEW REGULATION LITE}

\section{Emissions Trading and Regulatory Philosophies}

As far as the UK is concerned, the philosophical significance of emissions trading lies in its shifting the implicit measures of regulatory quality and legitimacy ${ }^{125}$. Since the late nineties, good regulation has been assessed, across government, with respect to the Five Principles of Good Regulation and the yardsticks of: Proportionality, Accountability, Consistency, Transparency and Targeting ${ }^{126}$. New concerns to reduce regulatory burdens ${ }^{127}$ have set the search for good regulation at tension with the quest for less regulation and have evidenced some philosophical confusion within government. ${ }^{128}$ The rise of emissions trading has taken place amidst that confusion and, it is contended here, has proven consistent with both newly thin notions of legitimacy and a weakening of expectations that good regulation should satisfy the Five Principles. Two separate but powerful assumptions can be seen, in turn, as consistent with such changed approaches to legitimacy and regulatory evaluation.

The first of these assumptions is that the emissions trading device is a kind of cost-free method of controlling emissions efficiently and accountably while reducing private sector compliance costs. ${ }^{129}$ Driesen ${ }^{130}$ argues that proponents of emissions trading employ a 'free lunch' metaphor in presenting such an

\footnotetext{
consumer information - space here does not permit exploration of the potential for different combinations of regulatory and market mechanism.

125 The word 'legitimacy' here is used to mean 'worthiness of support' (rather than 'entitlement to rule'). A large element of such legitimacy turns on the acceptability of accountability mechanisms but other factors, such as fairness, transparency and effectiveness, will also be relevant - see R. Baldwin and M. Cave, Understanding regulation (Oxford: Oxford University Press, 1999) Chapter 3; see also J. Black, 'Contesting Accountability and Legitimacy' forthcoming.

126 See now: BRTF, 'Principles of Good Regulation' (London, Cabinet Office, 2003). On measuring regulatory quality generally see R Baldwin and M Cave, ibid; C. Radaelli and F. De Francesco, Regulatory Quality in Europe (Manchester: Manchester University Press, 2007) Chapter 2.

127 See P. Gershon, Releasing Resources for the Frontline: Independent Review of Public Sector Efficiency H M Treasury, July 2004; Better Regulation Task Force, Avoiding Regulatory Creep (Cabinet Office, London, 2004); Better Regulation Task Force, Regulation - Less is More (Cabinet Office, London, 2005). P. Hampton, Reducing Administrative Burdens (London: HM Treasury, 2005).

128 See R. Baldwin, 'Better Regulation: Tensions aboard the Enterprise' in S. Weatherill, Better Regulation in Europe (Oxford: Hart Publishing, 2007); 'Is Better Regulation Smarter Regulation [2005] Public Law 485.

129 See Ackerman and Stewart, 'Reforming Environmental Law: the Democratic Case for Market Incentives', n 23 above.

${ }^{130}$ See Driesen (1998), n 47 above, 1-3 (who prefers to call this the 'cheap fix' argument).
} 
argument. ${ }^{131}$ This is a metaphor that suggests that there are no real losers in distributing pollution rights by auctions or other allocation methods and then allowing trading. Efficiency is held to be the winner and rights will flow to those parties who will maximise the value that can be extracted from the relevant emissions- causing processes. In defence of the Stern Review it might be noted that its authors did accept that issues of distributional and social justice, as well as development, arise when emissions trading devices are used. Once the existence of such issues is acknowledged, however, the advocates of trading tend to deal with the solutions to such thorny problems in a manner consistent with the 'free lunch' metaphor. Thus, emissions trading is lauded as possessing the virtue of bringing distributional issues out into the daylight and little is made of its built-in tendency to exacerbate wealth and development inequalities. Emissions trading is portrayed as fair and being progressive in effect. ${ }^{132}$ This picture flows from the placing of emphasis on short term gains to less well off parties and the underplaying of the longer term losses that trading will impose on those same actors. ${ }^{133}$ This portrayal is exemplified in the Guardian writer Polly Toynbee's analysis of trading:

Miliband's electric radicalism comes in his plan for personal carbon allowances. Here is where social justice meets green politics for the first time. Give every citizen the same quota of energy and let them buy and sell it on the open market. The half of the population who don't fly will make money from selling their quota to the half who do. Drive a gas-guzzling $4 \times 4$ and you will have to buy a quota from the third of the population with no access to a car. Who could complain about such transparent fairness? .......it in effect redistributes money from the rich to the poor, from the frequent flyers to never-flyers, with a parallel currency. ${ }^{134}$

Respondents to such an approach would, however, be sure to complain. They would contend that the commodification of rights to emit carbon constitutes not 'transparent fairness' but a means of magnifying wealth differentiations and of

\footnotetext{
131 See also Greenspan Bell, n 85 above - who criticises the 'free lunch' image of trading.

132 On the discourse of 'ecological modernisation' ( as now encountered across commentators and policymakers in Europe, North America and elsewhere) and optimism regarding the potential to meet economic, social and environmental objectives in a manner that does not threaten market principles, see generally M. Hajer, The Politics of Environmental Discourse: Ecological Modernisation and the Policy Process (Oxford: Oxford University Press, 1995); S. Young, The Emergence of Ecological Modernisation (London: Routledge, 2000).On the relationship between markets and regulation see J. Braithwaite, Markets in Vice Markets in Virtue (Oxford: Oxford University Press, 2005).

133 See S. Dresner and P. Ekins, 'The Distributional Impacts of Economic Instruments to Limit Greenhouse Gas Emissions from Transport' PSI Research Discussion Paper 19 (London: PSI, 2004) and the discussion of Domestic Tradable Quotas (at Section 8) which assesses winners and losers on the basis of the costs of quotas for households but leaves the opportunity costs of selling allowances out of account. See also the claims that individual carbon trading can be "moderately progressive" in S. Roberts and J. Thumim, A Rough Guide to Individual Carbon Trading (London: Defra, 2006) 5.

134 Polly Toynbee, 'This Electric Radicalism Marries Green Politics With Social Justice' The Guardian 15 December 2006.
} 
pricing poorer citizens out of their enjoyment of life's benefits - just as congestion charging prices the poor off the roads. Toynbee argues that the gas guzzling $4 \times 4$ owner: 'will have to buy a quota' but the critics would describe matters differently: 'the rich gas- guzzling $4 \times 4$ owner is given a chance to buy the road and exclude the poorer motorist from the highway.' Such critics might observe that when Robin Hood took from the rich and gave to the poor he did not, in return, limit the poor's entitlements to exploit the resources of Sherwood Forest.

The 'free lunch' conception of emissions trading breaks down on scrutiny. Enough was said in Part 2 above to indicate that emissions trading, at least in some forms and contexts, is subject to question on a number of fronts - notably regarding its objectives, efficiency, fairness, transparency and accountability. Nor is it convincing to argue that this is a device that falls to be judged by the canons of market accountability - the problem with emissions trading is that, even if trading is healthy, the market may not deliver an acceptable set of outcomes by means of acceptable processes.

The second assumption consistent with a shift towards thinner expectations of legitimacy is the realpolitik notion that this mechanism is acceptable because it can be implemented. Emissions trading may be viewed as 'regulation lite' by critics because it frequently involves controls and allocations that are designed not to frighten the horses of the incumbents. That, 'lite' quality, however, may be welcomed by many governments on the grounds that, at least on the world stage, we face global warming issues of such urgency that the best regulatory method for controlling greenhouse gases is the one that has the best chance of implementation. Subscribers to this view are likely to contend that when US President, George W Bush rejected the Kyoto Protocol, this constituted a wake up call that forced the EU to realise that without accepting market mechanisms, the Protocol would never come into force. ${ }^{135}$ They might add that, since 1992, prior attempts to introduce carbon taxes had failed and no other policy instrument was delivering emission reductions.

Emissions trading, moreover, can be said to possess three valuable attributes that make it a specially attractive proposition when acceptability is at issue. First, it holds out the prospect of a precise goal (the overall emissions cap) combined with a procedural framework, and, as such, it provides an identifiable aim that different parties or countries can negotiate and agree on. Its implementability is its strength. Second, it allows a nettle to be grasped now while deferring the resolution of difficult issues to a later date. (As where the EU ETS deferred many issues by moving them into the entitlements allocation processes). Third, emissions trading both appeases powerful players (by accepting their incumbent positions as givens) and it also offers short term compensation to less well placed parties. All of these properties have been picked out by proponents of emissions trading. Gordon Brown welcomed the Stern Review by emphasising that action on the environment had to be taken with urgency, that the UK was attempting to build a

135 Butzengeiger and Michaelowa, n 39 above, 116. 
consensus because: 'In a globally competitive economy a multilateral approach is the only way forward' The Kyoto Treaty and the EU ETS were of key importance, said Mr Brown: 'They make the economic opportunities of a climate friendly policy real and tangible. ${ }^{136}$ These comments echoed Stern's assertion that it was essential 'to create a shared international vision of long term goals and to build international frameworks. ${ }^{137}$ What was on offer, then, was not only a focussed target but economic opportunities for business and the instigation of some action for green pressure groups - thus friends of the Earth dubbed the EU ETS :'... a potentially huge step forward in the race to tackle climate change. ${ }^{138}$ Left out of account in such reactions, though, are the foregone opportunities suffered by sellers of allocations. Powerful players are kept happy by being presented with a low cost way to meet emissions limitations, by the ability to buy cheap credits, and by grandfathering or the use of historic allowances. The Green lobby sees some action and is told by Polly Toynbee and other commentators that all is fair since they are to be compensated for any lost rights to pollute.

Where, though, does this leave any analysis of regulatory quality? Good regulation - or at least good emissions trading - appears no longer to be judged with reference to the Five Principles. Two tests seem to come to the fore. First, whether it has the potential to address an issue of catastrophic risk. (Anything that works in an emergency is acceptable.) It can be implemented and notions of accountability and fairness are demoted in importance: because effectiveness in achieving objectives is paramount; or because there are assumed to be no losers within trading systems; or because public notions of accountability are deemed to be adequately replaced with accountability through markets. Second, emissions trading is held to be good because it is efficient - it provides a desired solution at lowest cost and it maximises utility by respecting the rights of incumbents.

The difficulty with the approach as described is that, as already noted, trading in itself does not do much at all to address the catastrophic risks facing the world - it merely offers a low cost option for action. There is, moreover, no free lunch there are significant losers within trading mechanisms - namely those who start off with fewer chips in life's poker game. Accountability to the market may exist but that market is skewed towards incumbents and powerful players. A final difficulty with emissions trading is that even if we were prepared to tolerate its weakness of accountability and fairness on the grounds of an anticipated response to a catastrophic risk, we cannot apply the same reasoning to non-catastrophic risk - such as the risks of traffic congestion. This is especially the case where alternative regulatory instruments might achieve similar objectives.

At this point it might be contended: why not opt for emissions trading because the available alternative modes of controlling pollution - such as

136 Gordon Brown - speech reported in The Guardian 30th October 2006.

137 Stern, xviii and Chapter 22.

138 Friends of the Earth, 'Carbon Emissions Trading Scheme Starts Without UK on Board' 24 December 2004. 
commands or taxes - are equally fraught with dangers (regarding, for example, manipulation by powerful interests) but emissions trading at least offers efficient responses and ease of implementation. Much depends, as noted, on how emissions trading is put into effect; on which version of trading is applied in a given context; and on the potential of steps that can be taken to reduce the negative effects of trading. Within these bounds of generalisation, though, the answer to the 'all systems are difficult' point is twofold. First, there are reasons, as indicated, to think that emissions trading, at least in certain circumstances, aggravates some of the problems commonly associated with traditional forms of command regulation. It, for instance, can involve particular incentives to manipulate, special incumbent advantages and notable difficulties of accountability and transparency. In addition it forgoes across- the- board standards in favour of less fair mechanisms that tend to reward past polluters. Second, it can be replied that if we are to choose emissions trading, we should not do so on a 'free lunch' basis or because 'all controls are fraught' but because we place primacy on its capacity for overcoming the opposition of the economically powerful. This leaves a final issue: how such regulation is to be justified to the broad public.

\section{JUSTIFICATION IN THE ERA OF EMISSIONS TRADING}

As far as theories of regulatory legitimation and accountability are concerned, there is an important message to be gleaned from the above discussion. This is that there may be material limitations on the extent to which 'market' mechanisms can be deployed constructively alongside traditional 'democratic' mechanisms of accountability, transparency or legitimation. This suggests, in turn, that a degree of caution may be appropriate regarding the possibility of developing coherent regimes of accountability in complex regulatory systems in which the state is not the sole locus of authority but where control functions are spread across a variety of state and non-state actors. ${ }^{139}$

Such caution contrasts with the optimistic vision of the 'redundancy' model of accountability. This model suggests that, in complex systems of modern government, control and policy functions are often spread across institutions and processes of different kinds, that conflicts and tensions exist within the complex accountability webs that apply within a regulated domain, but that:... 'the objective should not be to iron out conflict, but to exploit it to hold regimes in appropriate tension. ${ }^{140}$ The approach is optimistic in so far as it stresses that the various accountability systems that operate concurrently in an area 'have the character of a complex system of checks and balances' which have the potential

\footnotetext{
139 See J. Black, 'Decentring Regulation: The Role of Regulation and Self-Regulation in a "PostRegulatory" World' (2001) 54 Current Legal Problems 103. On ecological modernisation see references at n 132 above.

140 See C. Scott, 'Accountability in the Regulatory State' (2000) 27 J. Law and Society 38, 57.
} 
for harnessing into an effective accountability system 'even as public power continues to be is exercised in more fragmented ways.' ${ }^{141}$

Experience with emissions trading suggests that there are a number of reasons why the sanguinity of the redundancy model may be inappropriate in the post-emissions trading era. This, in short, is because emissions trading systems can raise accountability and legitimation challenges to unprecedented levels. Even before the rise of emissions trading those challenges were rendered severe by the development of 'decentred' regulatory systems. In decentred systems the mechanisms and processes of holding to account involve not merely variations in institutions, procedures, discourses, ${ }^{142}$ systems and expectations across actors or constituencies, but also the potential for destructive, rather than harmonious, interactions between mechanisms. Such difficulties arise, for instance, when certain types of accountability relationships are constructed between parties in ways that are at tension with other relationships. This can occur because different processes are used but also where different frames of meanings, values and objectives are involved. ${ }^{143}$

In the case of emissions trading, however, such difficulties are raised to a new level by three significant factors. First, the assumptions that underpin some accountability relationships within trading are inconsistent with other modes of control. Thus, the assumption that emissions trading processes involve no losers is compatible with an efficiency-based reliance on market controls but it does not sit easily with the notion that less affluent citizens need democratically based protections from the distributional consequences of market transactions.

Second, within emissions trading there are control systems that operate with inconsistent core tenets. Thus, the idea that the market will allocate emissions abatements in an uncontentious manner is at odds with beliefs that the starting points of markets call for adjustments to be made on the basis of some model of social justice. The view that distributional decisions can be overlaid on market mechanisms in a transparent way is liable to be heavily disputed by those who think that such efforts will, at best involve tinkering in the face of the overwhelming need to preserve the workings of the market.

Third, there are incompatibilities within the system regarding the very needs for legitimacy and accountability. Emissions trading is not a system in which 'market' and 'democratic' checks and balances can be brought into line with any harmony. Normally an observer might view a ' market' mechanism as bringing

\footnotetext{
141 ibid, 55; for another arguably optimistic view see L. Stirton and M. Lodge, 'Transparency Mechanisms: Building Publicness into Public Services' (2001) 28 J. Law and Society 471. ('Using a wide selection of [accountability] mechanisms may enhance the protection of citizen welfare....Arguably it is primarily through the opposition of competing centres of control that it becomes possible to achieve transparency ...' (at 488-9). It should be noted that Scott, Stirton and Lodge are not unaware of the conflicts and tensions that exist between control systems.

142 See J. Black, n 139 above; 'Talking About Regulation' [1998] PL 77-105; 'Regulatory Conversations' (2002) J. Law and Society 163.

143 See J. Black, n 139 above.
} 
accountability to consumers, shareholders and other stakeholders and might see 'democratic' mechanisms as ensuring accountability to citizens and participants. In emissions trading, however, the 'market' is self-regarding and 'closed' in nature so that (without strong corrective instruments) there is not even an effective regime of control by consumers, shareholders or others. Governments who institute emissions trading systems allocate permits for trading between polluters, not between polluters and consumers. Such governments, accordingly, are involved in a process that relinquishes their own roles as holders to account and only reasserts this when they supplement trading with further controls or reset the emissions caps or baselines. They do not give up this regulatory role in favour of holding to account by consumers but set the market free - often on the grounds that this is justifiable because the need for some action to combat emissions trumps any needs for legitimation beyond the group of potential compliers. Trading systems, accordingly, constitute 'accountability black holes' and, as such, cannot be harnessed alongside other accountability mechanisms in a coherent legitimising mesh. Regarding legitimation, there might be said to be mush, not mesh.

The optimistic view of redundancy stresses the potential of harmony and coherence in concurrent accountability mechanisms. The pessimistic vision suggests that redundancy theory may offer a valuable perspective on control regimes but that there are good reasons for thinking that mixtures of accountability systems will sometimes produce confusions, uncertainties, injustices and democratic deficits. This is liable to occur when there are inconsistencies in the assumptions that form the basis for controls, when there are incompatibilities of relevant values, discourses and visions of accountability, and when there are variations in the accountability objectives of different systems. ${ }^{144}$ The challenge for public lawyers and the designers of regulatory systems may be to make appropriate interventions in order to make complex networks of accountability work. ${ }^{145}$ The emissions trading experience, however, suggests that such a challenge may be Herculean when the above three factors are encountered..

\section{CONCLUSIONS}

Emissions trading, it has to be repeated, operates with quite different strengths and weaknesses in different contexts and in its different design vesions. With that caveat in mind, and, in the light of the above discussion, how is the rise of emissions trading to be responded to? There are, perhaps, two ways forward. One is to accept that 'anything goes' - that when faced with catastrophic risks, it is churlish to complain about legitimacy, accountability, or inherent biases in markets. The other way is to resist the optimistic view of redundancy and to reassert democratic values. This will involve contending, first, that arguments predicated on the confronting of catastrophic risks should not be applied in the

\footnotetext{
144 See Black, n 139 above; R. Baldwin and J. Black, 'Really Responsive Regulation' forthcoming. 145 n 140 above, 57.
} 
case of non-catastrophic risks, and, second, that it is especially when faced with potential catastrophes - and when the most dramatic decisions are taken - that we have to be most wary of the optimistic (or 'romantic') vision of redundancy and most reluctant to settle for confused regimes of control and legitimation.

The modern use of emissions trading has produced a model of 'regulation lite' that is resonant with assumptions that are hugely contentious. If we are to be more positive about the use of emissions trading we might say that it has produced a level of philosophical confusion about regulatory virtue that is patent enough to create two important opportunities. The opportunity arises for governments (and for commentators) to reformulate their conceptions of good regulation and to lay to rest any notions that 'less' regulation is always desirable or that regulation through trading is wholly acceptable because it involves no losers or because, in desperate circumstances, we have no choice. The opportunity for regulatory theorists is one that should not be spurned. It is to confront the difficulties of combining different systems of legitimation rather than to take refuge in all too comfortable beliefs in cumulative checks and balances. 